\title{
A Systematic Review on Oral Health Care Programs for the Elderly in Korea (2009 2020)
}

\author{
Eun-Seo Choi*, Im-Hee Jung*, Do-Ah Kim, Eun-Som Lee, and Hee-Jung Lim ${ }^{\dagger}$ \\ Department of Dental Hygiene, The Graduate School of Health Science, Eulji University, Seongnam 13135, \\ Korea
}

\begin{abstract}
Background: Various oral health management programs in Korea affect the oral health improvement in the elderly Several studies have been conducted to date; however, those studies have not shown uniform results due to the differences in research methods or designs. Hence, this study aimed to review the overall research trends of the reported oral health care programs for the elderly in Korea, verify their effects, and clarify them based on the systematic literature review.

Methods: The literature search selected intervention studies that applied the oral health care program for the elderly in Korea from 2001 to 2020. Following the COre, Standard, and Ideal (COSI) models presented by the US National Library of Medicine, we selected databases including Korean studies Information Service System (KISS), ScienceOn, Research Information Sharing Service (RISS), DBpia, PubMed, and Google Scholar. Of the 1,335 studies searched using keywords, titles, and abstracts, 21 were finally selected based on primary and secondary exclusion criteria.

Results: The most frequent intervention period was 4 weeks, and the number of interventions varied between 2 and 90 times. As for the type of intervention, 14 studies that conducted both theory and practice were the most frequent. Significant differences in the clinical indicators, such as calculus, halitosis, salivation rate, swallowing function, and dry mouth, were found in most oral health care programs.

Conclusion: Based on the results of this study, the intervention program needs further verification using multiple indicators in future studies. In addition, a study extending the intervention period and the number of samples is considered necessary for verifying continuous effectiveness of the intervention program.
\end{abstract}

Key Words: Elderly, Health plan implementation, Oral health, Systematic Review

\section{Introduction}

Recent advances of healthcare technologies and extended average lifespan as a result of improved standard of living and expanded healthcare services, there has been a dramatic expansion of the elderly population, which has led to a growing prevalence of a variety of physical, social, and mental health problems in this population ${ }^{1)}$.

Most of the health problems affecting older adults are physical and functional problems, and $38.1 \%$ of older adults aged 65 and over were found to suffer from oral health problems $^{2}$. In general, older adults show reduced salivary secretion as a result of aging and drugs. This leads to oral diseases such as dry mouth, impaired mastication, pronunciation, and swallowing, periodontal diseases, and tooth $\operatorname{loss}^{3}$. Such oral health problems affecting older adults are closely linked to systemic health as well as oral healthrelated quality of life (OHRQOL) ${ }^{4}$. Therefore, routine prevention and management are crucial. However, older adults accept these oral problems as a natural process of aging ${ }^{5)}$. Hence, continuous oral health management programs that enhance oral functions and prevent oral diseases in

${ }^{\dagger}$ Correspondence to: Hee-Jung Lim, https://orcid.org/0000-0002-4738-3032

Department of Dental Hygiene, The Graduate School of Health Science, Eulji University, 553, Sanseong-daero, Seongnam 13135, Korea

Tel: +82-31-740-7228, Fax: +82-31-740-7352, E-mail: cindy-1109@eulji.ac.kr

*These authors contributed equally to this work. 
older adults by altering their perception, behavior, and attitude are needed ${ }^{6}$.

Previous studies reported that oral health management programs influence older adults' dental plaque management $^{7,8)}$, denture hygiene management ${ }^{9}$, oral environmental management ${ }^{9)}$, dry mouth ${ }^{10,11)}$, bad breath ${ }^{12)}$, salivary secretion rate ${ }^{13,14)}$, mouth opening ${ }^{15)}$, orbicularis oris muscle strength $^{10)}$, voluntary behavioral change to promote oral health ${ }^{11)}$, change of perception about oral health ${ }^{10)}$, and OHRQOL $^{11)}$.

As shown here, various oral health management programs in Korea are important factors that affect older adults' oral health management. However, describing and comparing the effects of various interventions as well as generalizing the effectiveness of these interventions are difficult due to the varying methods of operation, research methodology, and associated factors. Hence, objectively assessing the effects of interventions through a literature review and presenting a direction for follow-up studies are crucial in substantiating the effectiveness of oral health management programs for older adults.

In this context, this study aims to review the trends of intervention studies involving oral health management programs for older adults and analyze the contents and outcomes of the interventions so as to evaluate the effects of these programs on older adults and to provide foundational data recommending the directions of future research on the topic.

\section{Materials and Methods}

\section{Literature search}

A literature search was performed with reference to the Korean version of Preferred Reporting Items for Systematic Reviews and Meta-Analysis (PRISMA), a modified and expanded version of the original tool ${ }^{16)}$. The literatures were selected based on the PICO (Participants, Intervention, Comparisons, Outcomes) strategy for systematic reviews. Participants $(\mathrm{P})$ were set to older adults $(\geq 60$ years in Korea) as defined as the elderly recipients of the national pension per the National Pension Act ${ }^{17}$. Intervention (I) was set to oral health management programs for older adults. Comparisons (C) were not specifically defined, and one-group pretest-posttest designs were also included. Outcomes $(\mathrm{O})$ were set to the effects of the program.

A literature search was conducted using Korean databases from November 2020 to May 2021. Based on the COre, Standard, and Ideal (COSI) model proposed by the US National Library of Medicine, the search was conducted in the COre databases of Korea as recommended by the National Evidence-Based Healthcare Collaborating Agency (NECA) and standard databases, namely Korean Studies Information Service System (KISS), ScienceOn, Research Information Sharing Service (RISS), and DBpia. Combinations of the search terms "older adults" for participants and "oral health management program," "continuous oral health management," and "oral health education" for intervention were used.

\section{Selection criteria}

Experimental studies that administered an oral health management intervention for Korean older adults aged 60 years and over were selected. Posters and conference proceedings were excluded, but theses and dissertations were included in addition to journal articles to review diverse interventions. Oral programs administered by nurses and certified nursing assistants trained by the researchers were also included. One-group pretest-posttest designs were also included, but studies that did not present the details of the oral health management program and studies that

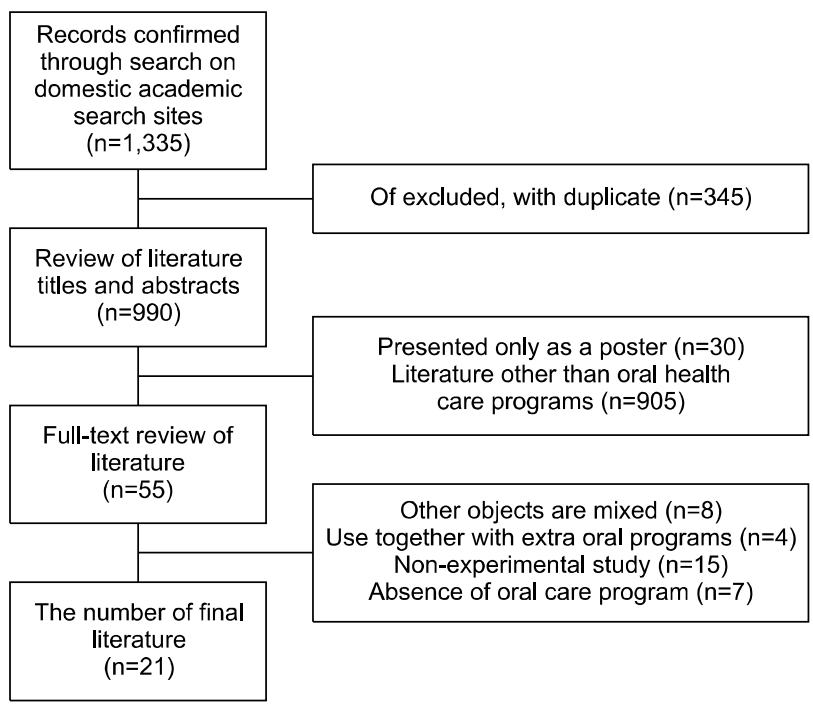

Fig. 1. A flow diagram for data collection. 
concurrently administered another type of health management program in addition to the oral health management program were excluded. In addition, studies with a study population comprising different age groups other than older adults were excluded. Based on this inclusion and exclusion criteria, 21 out of 1,335 search results were selected in this descriptive literature review (Fig. 1, Table $1,2)$.

\section{Analysis}

The general characteristics of the 21 included studies were described by publication year, sample size, sex of participants, study design, and setting of study. The interventions were described by intervention frequency, duration of intervention, type of intervention, contents of intervention, and effects of intervention, and the data were analyzed with frequency analysis using the 2017 IBM SPSS Statistics version 25 (IBM Corp., Armonk, NY, USA). The statistical significance level was set at 0.05 .

\section{Results}

\section{General characteristics of included studies}

The most common publication year was between 2016 and 2020 (11 studies), and the most common sample size was 50 to 99 (11 studies). Seventeen studies enrolled both male and female, and the most common study design was nonequivalent pretest-posttest design (16 studies). The most common setting of study was long-term care center, followed by senior centers, long-term care hospitals, and senior schools (Table 3, 4).

\section{Results of intervention of studies}

Table 5 shows the duration, number of sessions, type, and contents of the oral health management interventions.

The most common duration of intervention was four weeks ( 6 studies), and the number of sessions of intervention ranged from 2 to 90 sessions. The most common type of intervention was mixed intervention consisting of theoretical education and hands-on training ( 9 studies).

Among clinical indices, the most significant changes were observed in dental plaque, followed by tongue coating, mouth opening, and bad breath $(\mathrm{p}<0.05)$. Changes of oral health behaviors were assessed in terms of toothbrushing effort, ability to manage oral environment, use of oral products, denture cleaning frequency, toothbrushing frequency, oral health behaviors, and voluntary preparation for dry mouth. Statistically significant changes were observed in oral health behaviors in all five studies included in the said assessment $(\mathrm{p}<0.05)$.

Changes of oral health perception were assessed based on interest in oral health in one study, and the changes were statistically significant $(\mathrm{p}<0.01)$. Changes in selfefficacy were assessed based on OHRQOL in six studies, and the changes were statistically significant $(p<0.05)$.

\section{Discussion}

This study aimed to analyze the trends of oral health management intervention studies and the effects of these interventions for the Korean elderly population ( $\geq 60$ years) by reviewing the methodology, contents, and outcomes reported in the literature and to present evidence data for developing oral health management programs for older adults.

Table 1. The Selection Criteria for Papers

\begin{tabular}{lll}
\hline \multicolumn{1}{c}{ Type } & \multicolumn{1}{c}{ Inclusion } & \multicolumn{1}{c}{ Exclusion } \\
\hline Year & $2009 \sim 2020$ & $<2021$ \\
Type of literature & Domestic journals, unpublished master's thesis & Foreign journals, books \\
Study object & Elderly $(\geq 60)$ & Adults $(<60)$ \\
Study design & NCGPPD, OPPD, RCGPPD & - \\
Contents & Intervention effect of oral care program & - \\
\hline
\end{tabular}

NCGPPD: non-equivalent control group pretest-posttest design, OPPD: one group pretest-posttest design, RCGPPD: randomized control group pretest-posttest design, -: not available. 
Table 2. References to the Intervention Studies

\begin{tabular}{|c|c|c|c|c|c|}
\hline Number & $\begin{array}{l}\text { Main } \\
\text { author }\end{array}$ & $\begin{array}{l}\text { Publication } \\
\text { year }\end{array}$ & Title & Publisher or journal & URL \\
\hline 1 & YH Lee & 2009 & $\begin{array}{l}\text { Effect of oral health management } \\
\text { program for the elderly in an urban } \\
\text { community }\end{array}$ & $\begin{array}{l}\text { Yeungnam University } \\
\text { Graduate School }\end{array}$ & $\begin{array}{l}\text { https://www.riss.kr/link?id=T1178 } \\
0067\end{array}$ \\
\hline 2 & KW Kim & 2010 & $\begin{array}{l}\text { Effects of oral hygiene improvement of } \\
\text { the elderly patients by caregiver's in } \\
\text { rural long-term care hospital }\end{array}$ & $\begin{array}{l}\text { Journal of } \\
\text { Agricultural } \\
\text { Medicine \& } \\
\text { Community Health }\end{array}$ & $\begin{array}{l}\text { https://www.koreascience.or.kr/arti } \\
\text { cle/JAKO201017241417217.pdf }\end{array}$ \\
\hline 3 & HJ Bok & 2010 & $\begin{array}{l}\text { Evaluation on home visiting oral health } \\
\text { programe for the elderly in rural } \\
\text { community }\end{array}$ & $\begin{array}{l}\text { Daegu Haany } \\
\text { University Graduate } \\
\text { School }\end{array}$ & $\begin{array}{l}\text { https://www.riss.kr/link?id=T1195 } \\
9779\end{array}$ \\
\hline 4 & DY Kim & 2012 & $\begin{array}{l}\text { Effect of a mouth exercise program on } \\
\text { improvement of functions and quality } \\
\text { of life related to oral health in the } \\
\text { elderly }\end{array}$ & $\begin{array}{l}\text { InJe University } \\
\text { Graduate School }\end{array}$ & $\begin{array}{l}\text { https://www.riss.kr/link?id=T1291 } \\
5296\end{array}$ \\
\hline 5 & CY Kim & 2012 & $\begin{array}{l}\text { Development and evaluation of a } \\
\text { dysphagia assessment tool and an } \\
\text { intervention program for the elderly in } \\
\text { the long-term care facilities }\end{array}$ & $\begin{array}{l}\text { Journal of the Korea } \\
\text { Academia-Industrial } \\
\text { Cooperation Society }\end{array}$ & $\begin{array}{l}\text { https://www.koreascience.or.kr/arti } \\
\text { cle/JAKO201210348673825.pdf }\end{array}$ \\
\hline 6 & YH Lee & 2012 & $\begin{array}{l}\text { The effect of oral care program for the } \\
\text { elderly women of the visiting oral } \\
\text { health care }\end{array}$ & $\begin{array}{l}\text { Journal of Dental } \\
\text { Hygiene Science }\end{array}$ & $\begin{array}{l}\text { https://www.koreascience.or.kr/arti } \\
\text { cle/JAKO201223263074780.pdf }\end{array}$ \\
\hline 7 & MM Cho & 2013 & $\begin{array}{l}\text { Promotion of periodontal health } \\
\text { through professional toothbrushing } \\
\text { and education on the use of the } \\
\text { interdental brush in the elderly }\end{array}$ & $\begin{array}{l}\text { Journal of Korean } \\
\text { Academy of Oral } \\
\text { Health }\end{array}$ & $\begin{array}{l}\text { https://pdfs.semanticscholar.org/0b } \\
\text { de/4a967f3188dc09f519d26ea7b } \\
\text { db06d628500.pdf }\end{array}$ \\
\hline 8 & HL Bang & 2014 & $\begin{array}{l}\text { The effect of an exercise-based } \\
\text { swallowing training program for } \\
\text { nursing home residents with stroke }\end{array}$ & $\begin{array}{l}\text { Journal of Muscle and } \\
\text { Joint Health }\end{array}$ & $\begin{array}{l}\text { https://www.koreascience.or.kr/arti } \\
\text { cle/JAKO201426059105224.pdf }\end{array}$ \\
\hline 9 & M Kim & 2015 & $\begin{array}{l}\text { The effect of oral health education for } \\
\text { the elderly using Qscan }\end{array}$ & $\begin{array}{l}\text { Journal of Korean } \\
\text { Society of Dental } \\
\text { Hygiene }\end{array}$ & $\begin{array}{l}\text { https://www.koreascience.or.kr/arti } \\
\text { cle/JAKO201527359533134.pdf }\end{array}$ \\
\hline 10 & WC Park & 2015 & $\begin{array}{l}\text { Promotion of oral health and quality } \\
\text { of life for elderly in korea }\end{array}$ & $\begin{array}{l}\text { Seoul National } \\
\text { University Graduate } \\
\text { School }\end{array}$ & $\begin{array}{l}\text { https://www.riss.kr/link?id=T1374 } \\
4487\end{array}$ \\
\hline 11 & YS Kim & 2016 & $\begin{array}{l}\text { The effect of oral function } \\
\text { improvement with oral exercise } \\
\text { program by elderly people }\end{array}$ & $\begin{array}{l}\text { Journal of Korean } \\
\text { Society of Dental } \\
\text { Hygiene }\end{array}$ & $\begin{array}{l}\text { https://www.koreascience.or.kr/arti } \\
\text { cle/JAKO201627038926293.pdf }\end{array}$ \\
\hline 12 & KY Lee & 2016 & $\begin{array}{l}\text { Effect of professional oral healthcare } \\
\text { program on the oral status of elderly } \\
\text { residents in long-term care facilities }\end{array}$ & $\begin{array}{l}\text { Journal of Dental } \\
\text { Hygiene Science }\end{array}$ & $\begin{array}{l}\text { https://www.koreascience.or.kr/arti } \\
\text { cle/JAKO201608967047029.page }\end{array}$ \\
\hline 13 & SH Lee & 2016 & $\begin{array}{l}\text { Comparison of effects according to } \\
\text { type of oral exercise program for } \\
\text { elderly in Gangneung city }\end{array}$ & $\begin{array}{l}\text { Journal of Dental } \\
\text { Hygiene Science }\end{array}$ & $\begin{array}{l}\text { https://www.koreascience.or.kr/arti } \\
\text { cle/JAKO201608967047021.pdf }\end{array}$ \\
\hline 14 & IS Jang & 2016 & $\begin{array}{l}\text { The effect of denture care skills } \\
\text { education program on denture } \\
\text { self-care, denture satisfaction and oral } \\
\text { health-related quality of life } \\
\text { (OHIP-14) among the elderly }\end{array}$ & $\begin{array}{l}\text { Journal of Korean } \\
\text { Biological Nursing } \\
\text { Science }\end{array}$ & $\begin{array}{l}\text { https://www.koreascience.or.kr/arti } \\
\text { cle/JAKO201607365702514.pdf }\end{array}$ \\
\hline 15 & GR Hong & 2016 & $\begin{array}{l}\text { Effect of an educational tooth-brushing } \\
\text { program using priming in an elderly } \\
\text { population with dementia residing in } \\
\text { nursing homes }\end{array}$ & $\begin{array}{l}\text { Journal of Korean } \\
\text { Academy of Oral } \\
\text { Health }\end{array}$ & $\begin{array}{l}\text { https://www.kci.go.kr/kciportal/ci/ } \\
\text { sereArticleSearch/ciSereArtiView } \\
\text {.kci?sereArticleSearchBean.artiId } \\
\text { =ART002153114 }\end{array}$ \\
\hline
\end{tabular}


Table 2. Continued

\begin{tabular}{|c|c|c|c|c|c|}
\hline Number & $\begin{array}{l}\text { Main } \\
\text { author }\end{array}$ & $\begin{array}{l}\text { Publication } \\
\text { year }\end{array}$ & Title & Publisher or journal & URL \\
\hline 16 & JY Jang & 2017 & $\begin{array}{l}\text { Effect of oral health promotion program } \\
\text { on the elderly in nursing homes }\end{array}$ & $\begin{array}{l}\text { Korean Society of } \\
\text { Alcohol Science and } \\
\text { Health Behavior }\end{array}$ & $\begin{array}{l}\text { https://www.earticle.net/Article/A2 } \\
99639\end{array}$ \\
\hline 17 & JH Han & 2017 & $\begin{array}{l}\text { Home visiting oral health program of } \\
\text { long term home care service and the } \\
\text { change of salivary bacterial counts in } \\
\text { denture }\end{array}$ & $\begin{array}{l}\text { Hanseo University } \\
\text { Graduate School }\end{array}$ & $\begin{array}{l}\text { https://www.riss.kr/link?id=T1446 } \\
5507\end{array}$ \\
\hline 18 & JH Kim & 2018 & $\begin{array}{l}\text { Effects of an oral self-care program on } \\
\text { the elderly's xerostomia and oral } \\
\text { health-related quality of life }\end{array}$ & $\begin{array}{l}\text { Journal of Korean } \\
\text { Academy of } \\
\text { Community Health } \\
\text { Nursing }\end{array}$ & $\begin{array}{l}\text { https://synapse.koreamed.org/uploa } \\
\text { d/SynapseData/PDFData/0200JK } \\
\text { ACHN/jkachn-29-382.pdf }\end{array}$ \\
\hline 19 & SH Moon & 2018 & $\begin{array}{l}\text { Effect of Integrated oral health care } \\
\text { program for older adults in long-term } \\
\text { care facilities }\end{array}$ & $\begin{array}{l}\text { Hanyang University } \\
\text { Graduate School }\end{array}$ & $\begin{array}{l}\text { https://www.riss.kr/link?id=T14874 } \\
498\end{array}$ \\
\hline 20 & $\mathrm{JY} O \mathrm{Oh}$ & 2018 & $\begin{array}{l}\text { The effect of systemic health and } \\
\text { salivary massage on saliva flow }\end{array}$ & $\begin{array}{l}\text { Dong-Eui University } \\
\text { Graduate School }\end{array}$ & $\begin{array}{l}\text { https://www.riss.kr/link?id=T15062 } \\
656\end{array}$ \\
\hline 21 & $\mathrm{CH}$ Im & 2020 & $\begin{array}{l}\text { Effects of oral care Interventions for the } \\
\text { older adult in long-term care hospital } \\
\text { on oral health and oral health related } \\
\text { quality of life }\end{array}$ & $\begin{array}{l}\text { Busan National } \\
\text { University Graduate } \\
\text { School }\end{array}$ & $\begin{array}{l}\text { https://www.riss.kr/link?id=T15665 } \\
683\end{array}$ \\
\hline
\end{tabular}

Table 3. General Characteristics of the Included Studies

\begin{tabular}{llr}
\hline Characteristic & \multicolumn{1}{c}{ Category } & \multicolumn{1}{c}{ Value } \\
\hline Year & $\leq 2010$ & $3(14.3)$ \\
& $2011 \sim 2015$ & $7(33.3)$ \\
Sample size & $2016 \sim 2020$ & $11(52.4)$ \\
& $\leq 49$ & $7(33.3)$ \\
& $50 \sim 99$ & $11(52.4)$ \\
Sex & $100 \sim 149$ & $3(14.3)$ \\
& Male \& Female & $17(81.0)$ \\
\multirow{3}{*}{ Study design } & Female & $2(9.5)$ \\
& NR & $2(9.5)$ \\
& NCGPPD & $16(76.2)$ \\
& OPPD & $4(19.0)$ \\
& RCGPPD & $1(4.8)$ \\
\hline
\end{tabular}

Values are presented as number (\%).

NR: not report, NCGPPD: non-equivalent control group pretestosttest design, OPPD: one group pretest-posttest design, RCGPPD: randomized control group pretest-posttest design.

A total of 21 Korean studies that administered an oral health management program among older adults and published in or before 2020 were selected through Korean databases. The trends of these studies as well as the methods and effects of oral health management interventions were
Table 4. The Settings of the Studies

\begin{tabular}{cll}
\hline Characteristic & \multicolumn{1}{c}{ Category } & Value \\
\hline Sample site & Long-term care hospital & $3(11.1)$ \\
& Long-term care center & $9(33.3)$ \\
& Senior center & $5(18.5)$ \\
& Senior welfare center & $1(3.7)$ \\
& University of the elderly & $3(11.1)$ \\
& Home care elderly & $1(3.7)$ \\
& Nursing home & $1(3.7)$ \\
& General hospital & $1(3.7)$ \\
& Community welfare center & $2(7.4)$ \\
& Long-term home care hospital & $1(3.7)$ \\
\hline
\end{tabular}

Values are presented as number (\%).

analyzed as follows.

Most of the studies were published between 2016 and 2020 (11 studies), with the least number of studies published prior to 2010 (3 studies). A variety of studies have been conducted on oral health among older adults as Korea became an aged society. This shows that interests on oral health management have been mounting in response to the dramatic expansion of the older adult population ${ }^{18)}$.

The most common setting of research was long-term 


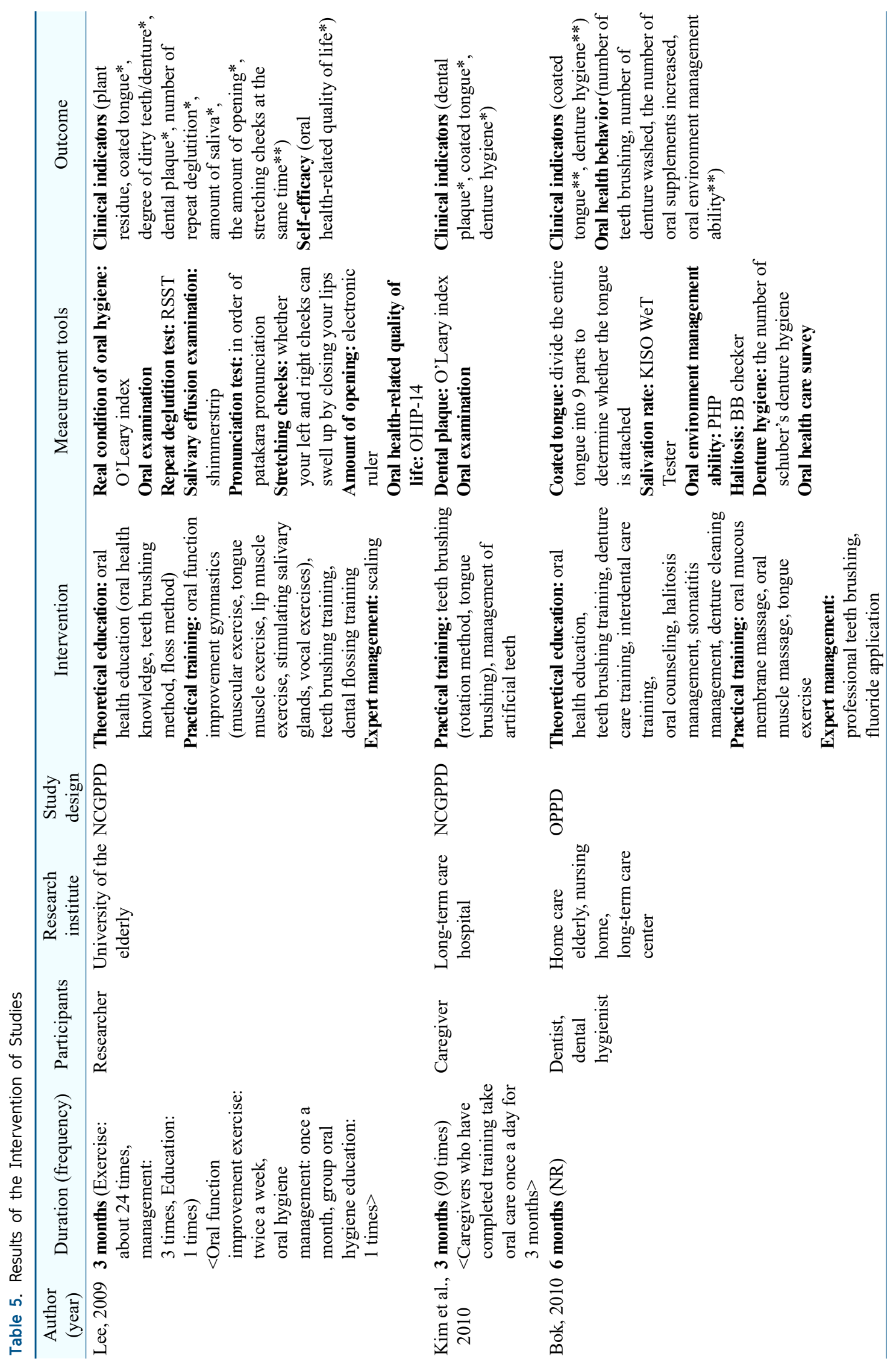




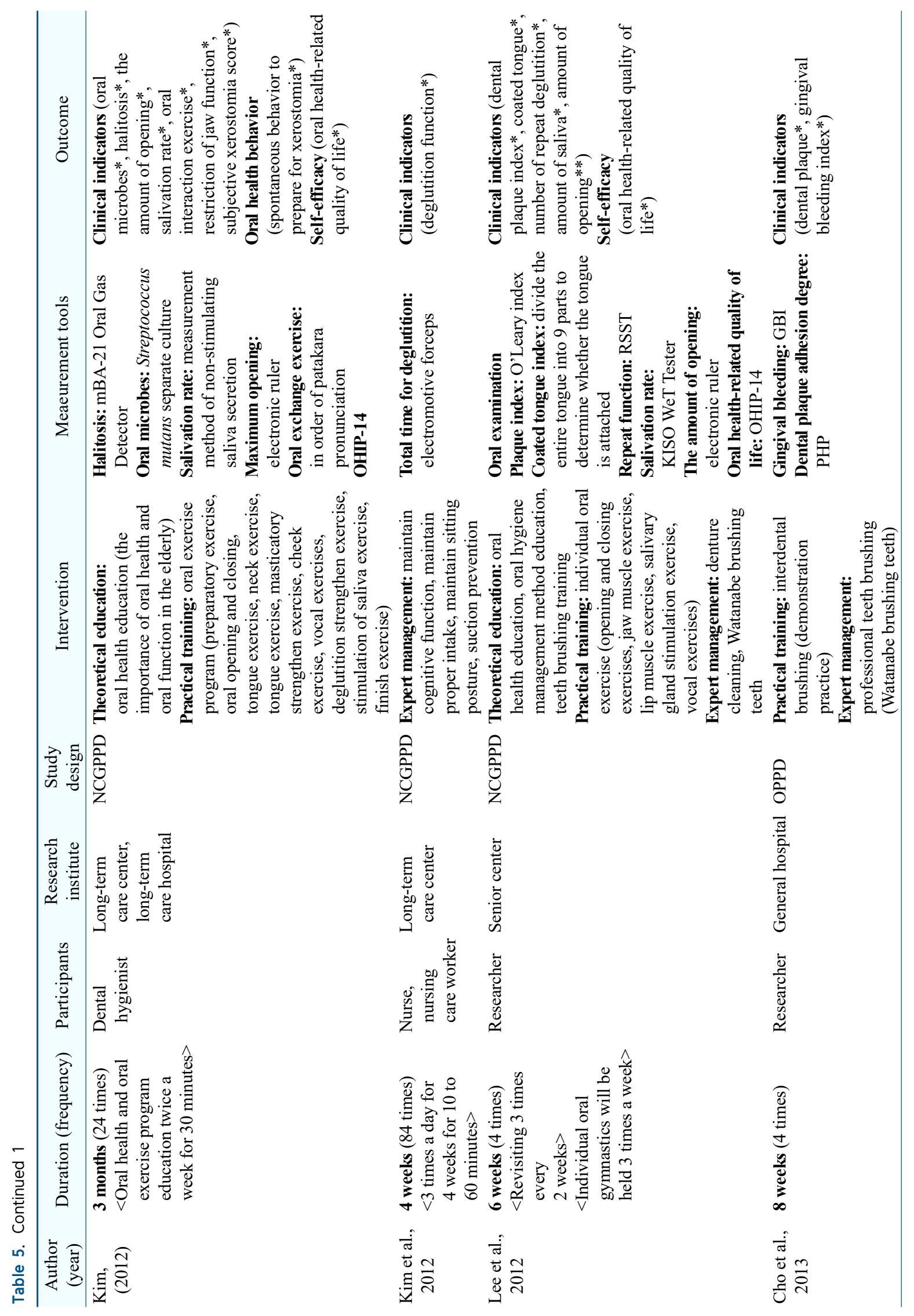




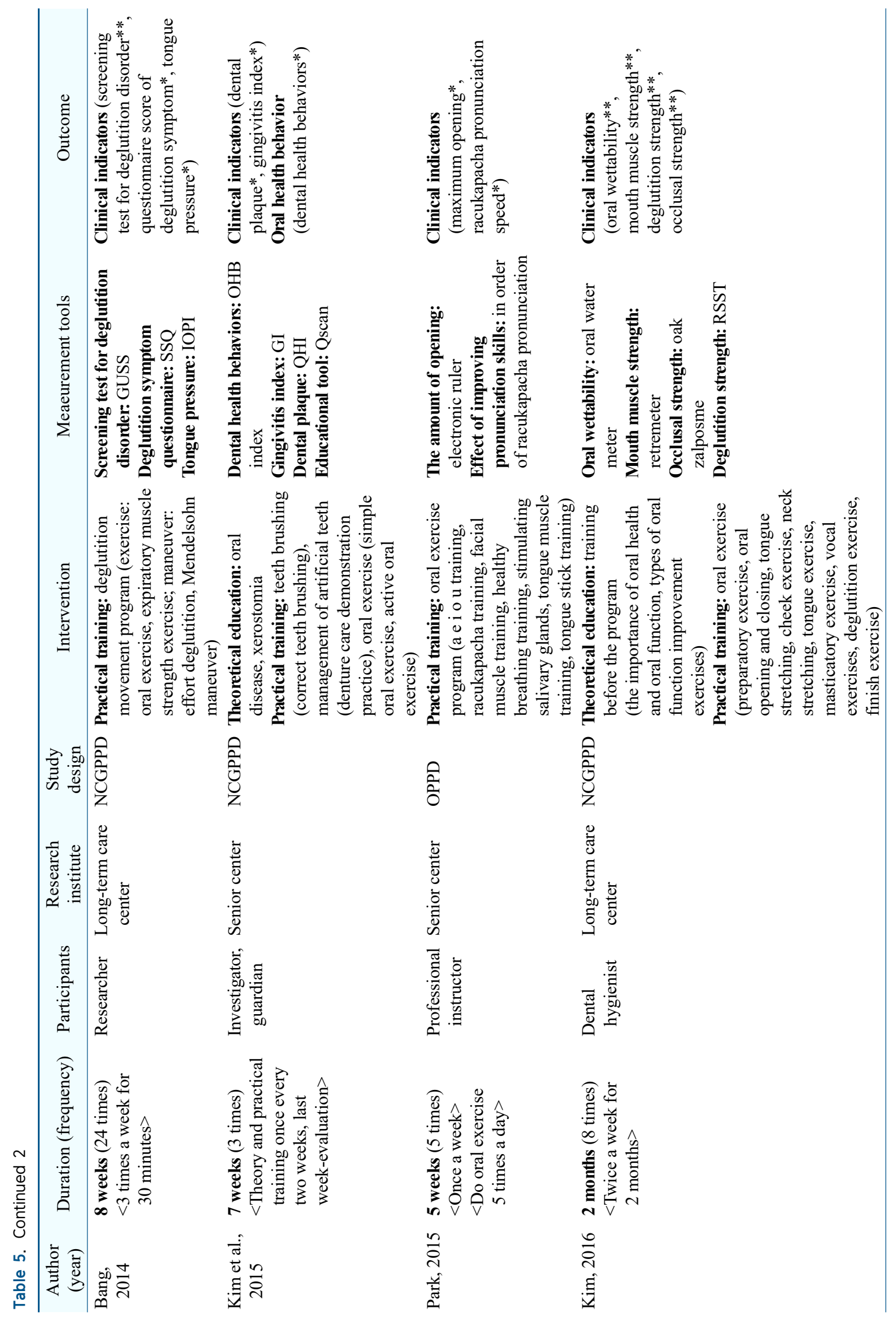




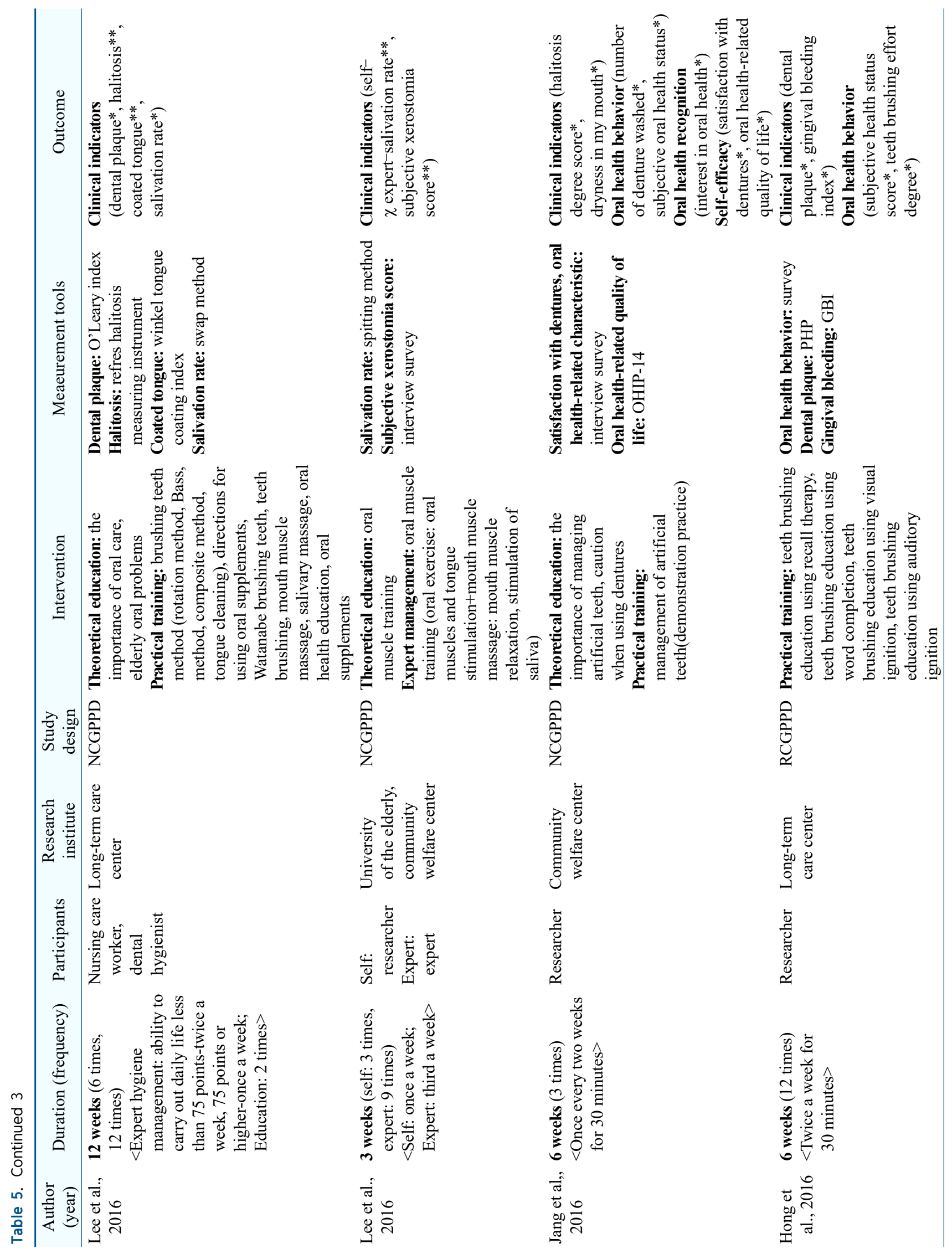




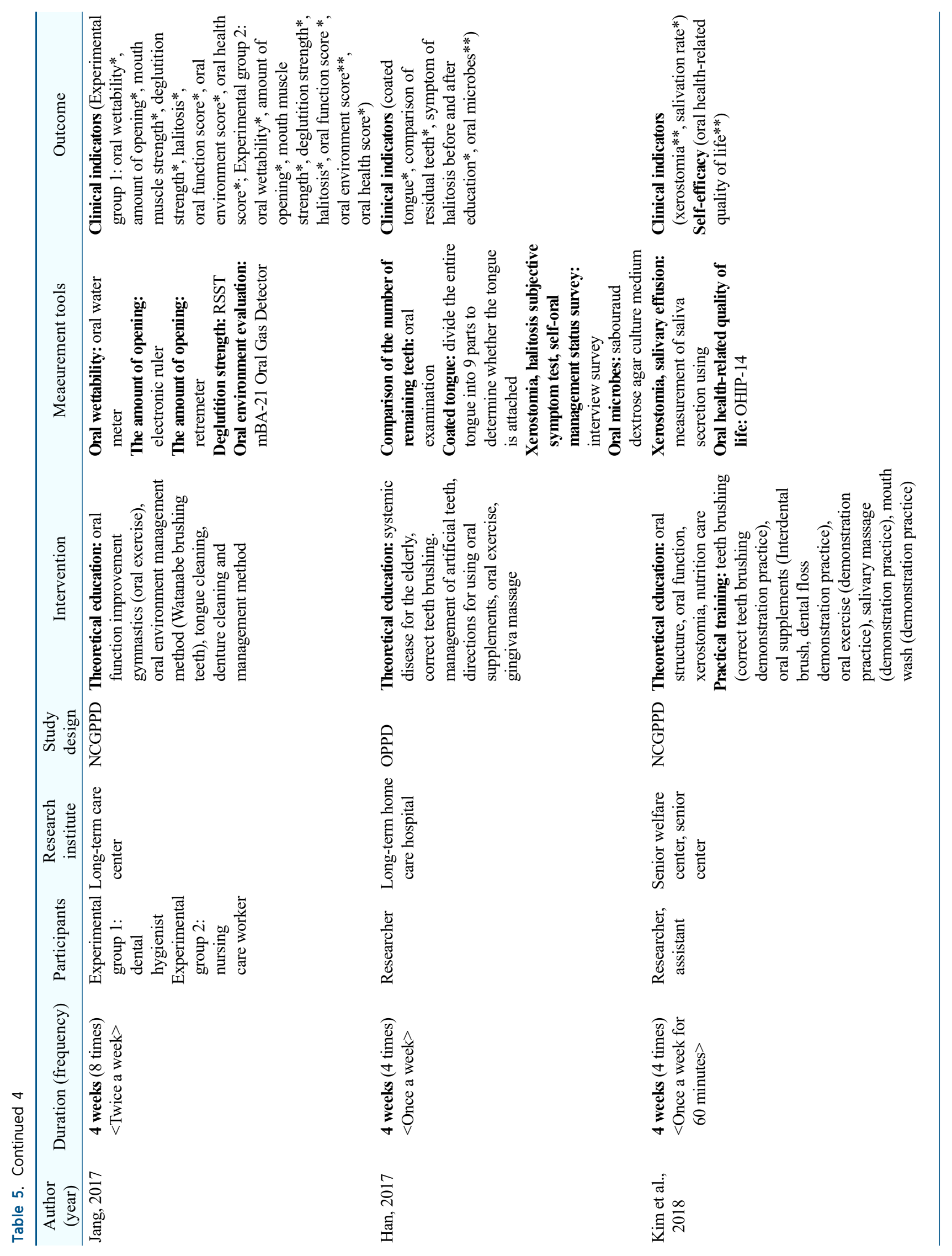




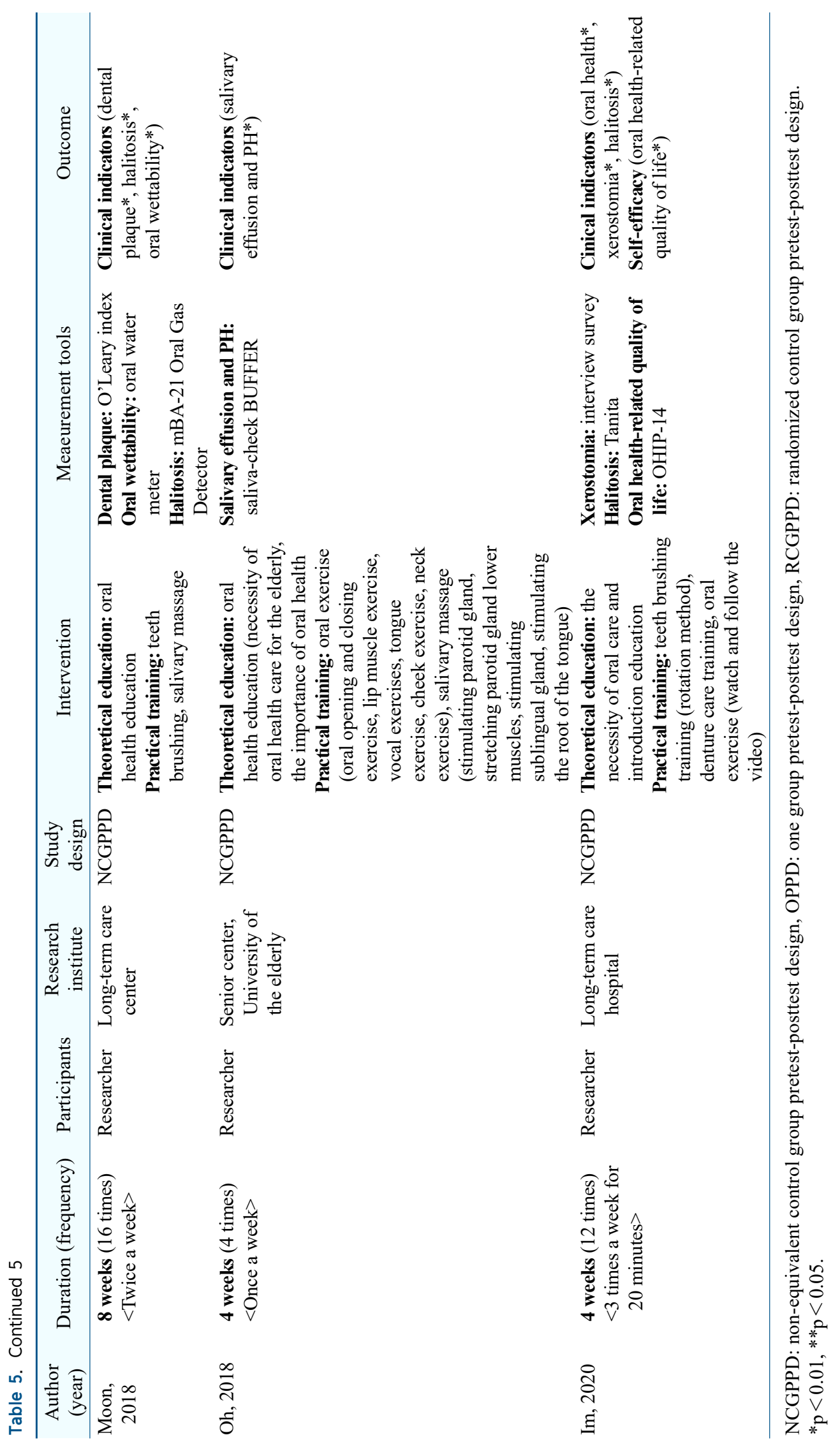


care center ( 9 studies), and studies were rarely conducted in a welfare facility for home-dwelling older adults or retirement homes (1 study). Older adults who utilize welfare centers for home-dwelling older adults are primarily those who live at home but are suffering from physical or mental disorders. Hence, studies should continue to examine older adults who do not have the luxury of receiving continuous professional management or interventions in order to promote the oral health of older adults in various settings. Accordingly, subsequent studies should be conducted on older adults in more diverse settings that have not been the focus of past research.

With the exception of one randomized controlled trial $(\mathrm{RCT})^{7}, 20$ studies were quasi-experimental studies. RCTs are recognized as the standard in clinical research and is a valid methodology with the least risk of bias and error, and more RCTs of oral health management programs should be conducted.

Most studies with a duration of intervention of four weeks or less only observed changes in the clinical indices, but studies that used an intervention lasting six months or longer observed changes in oral health behaviors, including toothbrushing frequency and ability to manage oral environment, as well. A short-term oral health education and professional oral management intervention would have limitations in bring about changes in long-established lifestyles. Regarding intervention frequency, most studies administered the intervention once a week. This is presumably because weekly repeated education enhances the performance of oral management intervention, considering older adults' cognitive abilities. Thus, long-term interventions ( $\geq 6$ months) would be needed in order to identify the specific effects of interventions and to enhance participants' performance with the intervention, and the frequency of intervention in long-term intervention studies should be set to once a week, as the frequency varied across the studies.

In addition, while oral health experts, such as dental hygienists, administered the oral health management interventions in most studies, the programs were administered by a certified nurse assistant or paid caregiver in four studies. However, the interventions produced significant outcomes in all studies regardless of the intervention trainer.
As the number of certified nurse assistants or paid caregivers providing continuous and routine oral health management is increasing, training these health-related workers with the administration of oral health education to promote older adults' oral health is also an important role of dental hygienists. Regarding the contents of the intervention, most of the studies investigated programs comprising oral exercise training and practice. This was presumably an effort to objectively confirm that oral exercise programs helped alleviate dry mouth and bad breath that are prevalent among older adults. The types of interventions included theoretical education (20 studies), hands-on training (18 studies), and professional management (6 studies). Jang et al. ${ }^{19)}$ reported that promotional event-based approaches, such as the creation of an oral health promotion environment and contests have the effect of increasing the effectiveness of health promotion programs, and Lee et al. ${ }^{13)}$ emphasized the importance of a certain degree of professional intervention. This is because participants are more engaged in new and diverse approaches, such as events, than unidirectional lectures, and involving professional management further engages the participants in the program based on trust in the professionals. Thus, subsequently, programs such as oral exercise or toothbrushing training should be administered in a demonstration-practice format to involve participants in the program, and these programs should also incorporate professional management, such as oral muscle massage or Watanabe toothbrushing technique, to further motivate voluntary participation among participants.

The effects of oral health management programs were assessed based on changes of clinical indices in all 21 included studies. These studies confirmed that oral health management programs have positive physical effects in older adults. Some studies also assessed the effects of oral health management programs based on the changes of oral health behavior, oral health perception, self-efficacy, and oral health knowledge. This is because it is important to alter older adults' behaviors, attitude, and knowledge through continuous and repetitive education and experience as part of oral health management programs. However, only five of the included studies assessed changes in oral health behaviors and knowledge. Therefore, future studies should 
concurrently assess the effects of the programs on several other indices of mental and social aspects in older adults.

This study adhered to the PICO and PRISMA guidelines for a systematic review but did not establish the validity of the included studies through a quality assessment. Further, only one of the included studies was a RCT, and oral health management programs used in other countries were excluded, thus hindering a more comprehensive literature review. Only 21 studies were selected based on the selection criteria, so the findings of this study cannot be generalized.

Despite these limitations, however, this study is significant in that it attempted to review the contents, methods, and effects of oral health management interventions for older adults. Subsequent studies should appraise the quality of the included studies to substantiate their validity and also include more relevant studies for a systematic review.

\section{Notes}

\section{Conflict of interest}

No potential conflict of interest relevant to this article was reported.

\section{Ethical approval}

This study is a review-based study and does not require an IRB review.

\section{Author contributions}

Conceptualization: Hee-Jung Lim. Data acquisition: all the authors. Formal analysis: all the authors. Funding: Hee-Jung Lim, Im-Hee Jung, and Eun-Seo Choi. Supervision: Hee-Jung Lim and Im-Hee Jung. Writingoriginal draft: all the authors. Writing-review \& editing: Hee-Jung Lim. All authors approved the final manuscript.

\section{ORCID}

Eun-Seo Choi, https://orcid.org/0000-0001-6968-4381 Im-Hee Jung, https://orcid.org/0000-0002-8645-1587

Do-Ah Kim, https://orcid.org/0000-0003-1239-3203

Eun-Som Lee, https://orcid.org/0000-0001-9566-6574

Hee-Jung Lim, https://orcid.org/0000-0002-4738-3032

\section{Acknowledgements}

This research was supported by 2021 Eulji university University Innovation Support Project grant funded.

\section{References}

1. Statistics Korea: 2019 Life expectancy. Retrieved June 12, 2021, from https://kosis.kr/statHtml/statHtml.do?orgId=101\&tblId= DT_1B41\&checkFlag=N.

2. Ministry of Health and Welfare: 2017 Elderly survey. Retrieved June 12, 2021, from http://www.mohw.go.kr/react/jb/ sjb030301vw.jsp?PAR_MENU_ID=03\&MENU_ID=032901\& page $=1 \& C O N T \_S E Q=344953$.

3. Kim JB, Kim GS, Kim YS, et al.: Public oral health. 5th ed. Komoonsa, Seoul, pp.106-107, 2020.

4. Lee HS, Kim HG: The effect of oral health index and dental prosthesis needs on oral health related quality of life in Korean elderly. J Korea Acad-Ind Cooper Soc 17: 72-78, 2016.

https://doi.org/10.5762/KAIS.2016.17.1.72

5. Korean Dental Association: Study on the dental treatment needs of elderly people covered by medical aid program. Retrieved June 12, 2021, from https://www.kda.or.kr/kda/kdaJournalOpen/ daJournalOpenCont1/journal_view.kda?journal_key=43\&pa ge $=9$.

6. Kim HS, Seok JJ, Kim HC, et al.: Study on tooth mortality after periodontal therapy. J Periodontal Implant Sci 33: 215-223, 2003.

7. Hong GR, Woo JS: Effect of an educational tooth-brushing program using priming in an elderly population with dementia residing in nursing homes. J Korean Acad Oral Health 40: 149-157, 2016. https://doi.org/10.11149/jkaoh.2016.40.3.149

8. Cho MM, Lee YH, Kim JB, Lee JH: Promotion of periodontal health through professional toothbrushing and education on the use of the interdental brush in the elderly. J Korean Acad Oral Health 37: 132-140, 2013. https://doi.org/10.11149/jkaoh.2013.37.3.132

9. Kim KW, Yoon HJ, Kim MR, Lee HK, Lee KS: Effects of oral hygiene improvement of the elderly patients by caregiver's in rural long-term care hospital. J Agric Med Community Health 35: 13-20, 2010. https://doi.org/10.5393/JAMCH.2010.35.1.013

10. Jang IS, Park SM: The effect of denture care skills education 
program on denture self-care, denture satisfaction and oral health-related quality of life (OHIP-14) among the elderly. J Korean Biol Nurs Sci 18: 239-246, 2016. https://doi.org/10.7586/jkbns.2016.18.4.239

11. Kim JH, Kim HY: Effects of an oral self-care program on the elderly's xerostomia and oral health-related quality of life. J Korean Acad Community Health Nurs 29: 382-392, 2018. https://doi.org/10.12799/jkachn.2018.29.3.382

12. Lee KY, Lim SR: Effect of professional oral healthcare program on the oral status of elderly residents in long-term care facilities. J Dent Hyg Sci 16: 432-441, 2016. https://doi.org/10.17135/jdhs.2016.16.6.432

13. Lee SH, Ryu JA, Yu HE, Lee JH, Shin SJ: Comparison of effects according to type of oral exercise program for elderly in Gangneung city. J Dent Hyg Sci 16: 424-431, 2016. https://doi.org/10.17135/jdhs.2016.16.6.424

14. Lee YH, Lee SK: The effect of oral care program for the elderly women of the Visiting oral health care. J Korean Soc Dent Hyg 12: 365-377, 2012. https://doi.org/10.13065/jksdh.2012.12.2.365

15. Jang JY: Effect of oral health promotion program on the elderly in nursing homes. Korean Soc Alcohol Sci Health Behav 4: 77-78, 2017.

16. Moher D, Shamseer L, Clarke M, et al.: Preferred reporting items for systematic review and meta-analysis protocols (PRISMA-P) 2015 statement. Syst Rev 4: 1, 2015. https://doi.org/10.1186/2046-4053-4-1

17. National Pension Service: 2017 Old-age pension. Retrieved December 1, 2021, from https://www.nps.or.kr/jsppage/info/ easy/easy_04_02.jsp.

18. Jang JH, Baik SH, Kim AJ, Jung SH, Kim OS, Kim SH: The effect of xerostomia on perceived oral health among elderly people wearing dentures. J Korean Acad Dent Health 30: 438-446, 2006.

19. Jang WK, Jeong GR, Kim CW: A review for the factors affecting the effects of health promotion programs. Health Policy Manag 12: 102-124, 2002.

https://doi.org/10.4332/KJHPA.2002.12.1.102 